\title{
THE RELATIONSHIP BETWEEN CORPORATE GOVERNANCE AND FINANCIAL PERFORMANCE IN ISLAMIC BANKS
}

\author{
Syed Amaar Ali Ausat \\ Department of Accountancy \& Finance, School of Social Science, \\ Heriot-Watt University Edinburgh, United Kingdom \\ Correspondence E-mail: aausat@aol.com
}

Received: June 2018; Accepted: October 2018

\begin{abstract}
Corporate governance refers to policies and mechanisms related to how the company is directed and controlled and looks at the Board of Directors and their characteristics for example. The focus of this study will be to investigate the relationship of corporate governance and financial performance for Islamic Banks. The corporate governance variables and financial data was collected using the Orisis database and looking through annual reports of the banks from 2013 to 2017. The sample comprised 12 listed Islamic banks from different countries and used a panel data approach with a set of 60 firm-year observations. The corporate governance variables selected included, board size, CEO duality, board independence and Shariah Supervisory Board size to test their effect of a firm's performance measured by ROA and ROE. Other firm level characteristics such as size and age of the banks were included to reduce the amount of external influence throughout the study. Results were analysed using descriptive statistics, Pearson Correlation Matrix, Generalised Least Squared (GLS) regression and the Random Effect Model. The concluding results proved that there was a positive relationship between some corporate governance variables and a firm's performance. Board size was reported as the most significant factor which affects financial performance as measured by ROA. However, interestingly CEO duality was also noted to be a significant factor which affected performance. This was seen for both performance measures; ROA and ROE. The remaining independent variables and control variables showed no significant correlation to a firm's performance and that there must be external factors which explain performance. The results showed that corporate governance was a necessary consideration for improved performance.
\end{abstract}

Keywords: Corporate Governance, Firm Performance, Islamic Banking, GLS Regression

JEL Classification: G34, L25, Z12, C23

\section{INTRODUCTION}

Corporate governance has been a concern in developed and developing countries due to the onslaught of corporate scandals which have highlighted the importance of corporate governance practices on the global economy (Vaughn \& Verstehen Ryan, 2006). Over the past few decades, many companies around the world, such as Enron, World Com and more recently, Carillion have suffered from failures in their corporate governance strategies from many problems relating to agency theory. The implications of maintaining good corporate governance has become an essential factor for improving a firm performance and encouraging economic development through the enhancement of investments (Price, Román, \& Rountree, 2011). Failures in corporate governance have seen some of the largest companies around the world collapse, further highlighting its significance.

As a result, many developed countries have established corporate governance rules and regulations that listed companies, in particular, must adhere to, in order to protect themselves and the public, for instance, the United Kingdom (UK) corporate Governance Code, (formally known as the Combined Code), published by the Financial Reporting Council in 2003, the US Sarbanes-Oxley Act in 2002 and Australian Stock Exchange (ASX) Corporate 
Governance Principles of 2002 (Otman, 2014). However, the principles outlined in these codes are largely derived from different recommendations by developed countries' governments and may not necessarily apply to all countries (Haniffa \& Hudaib, 2006). Each country has a unique social and economic climate, meaning that certain rules and regulations that apply in one country, may not be as applicable in another. Similarly, each corporation is based on many differing factors, such as culture, religion, history and objectives and therefore corporate governance strategies should take this into account. This is especially relevant in the case of Islamic banks (Haniffa \& Hudaib, 2006).

Islamic Financial Institution (IFI) is a term used to describe the different types of institutions that comprise the Islamic financial industry which mainly consists of banks, accounting firms and finance companies. These companies' activities are consistent with the Islamic rule of Law (Shariah Law) and are guided by principles of Islamic economics. The underlying principles of Shariah compliant finance is described by Samra (2016), as financing activities which include; the prohibition of interest (Riba) which translates to 'an unjustified increase', prohibition of financing prohibited (haram) industries (e.g. sale of alcohol, pork bellies, tobacco), prohibition of excessive risk taking (Gharar) and the quest for a just and ethical society which includes the payment of obligatory charitable contributions (Zakat). A profit sharing concept is used within investing activities, where the return to investors is linked to profits of the activity, which is derived from risk. A 'Sukuk' is the most common form of investment and is similar to a bond and uses a profit sharing system. There are also other forms of investment including 'Ijara' which is similar to a lease and is used as an alternative to mortgages for homeowners or leasing a car, for example (Samra, 2016).
According to the Global Islamic Finance Report (2017), IFIs currently contribute over US\$ 2.293 trillion to the global market and operate in over 75 countries which has seen growth of $7-10 \%$ annually in the last three years. This sector has provided consumers access to an alternative financing method that conforms to religious Islamic law or Shariah. Although certain practices differ with regards to IFIs, it should not be assumed that there is little need for corporate governance, just because the Islamic value system inherently protects the rights of stakeholders (Ahmed \& Chapra, 2002). Over the years, Islamic banks have also seen major collapses due to corporate governance breaches, such as the demise of the Islamic Bank of South Africa in 1997 and the corporate fraud seen in the Dubai Islamic Bank in 2004. This provides a significant reminder that like conventional banks, Islamic banks require robust corporate governance systems.

The following figure shows the progression of growth in Islamic Banks and Financial Institutions (IBFI) from 2007 and 2016 worldwide, including future forecasts.

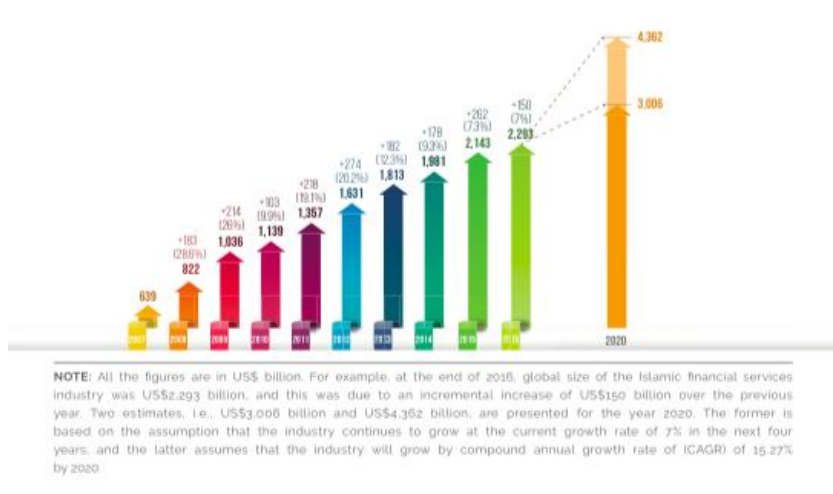

\section{Figure 1. Size and Growth of IBFI between 2007 and 2016 with Future Growth Prospects}

Source: GIFR (2017)

Given the continued growth of Islamic banking and the increase in corporate scandals, it is important to examine corporate governance mechanisms which contribute to improved performance and the continued success of the firm. 


\section{RESEARCH METHOD}

\section{Type and Data Sources}

The data types, employed throughout this research, include market and accounting based data. The data is exclusively secondary data, obtained primarily from annual reports, as well as from the Orisis database. The independent variables were obtained from annual reports of the Islamic banks and the dependent and control variables were obtained from the Orisis database. Orisis is a very practical and easy tool to use to gather company and financial data for companies worldwide, which was extremely beneficial. The annual reports were downloaded and examined to find the corporate governance information required regarding the companies.

\section{Data Samples dan Period}

The data sample chosen was based on public Islamic banks throughout the world. The Banks were ranked in terms of size of assets and the largest 12 banks were chosen. Selected firms were extrapolated from Orisis, but the choice of firms was dependent on availability of information. Companies, where annual reports were not available, were excluded, as many Islamic banks do not follow the same regulations as conventional banks and therefore often partial information only was available. Due to the nature of the Islamic banks, most banks were located in the Middle East and Asia.

To ensure the reliability of the study, a long sample period was chosen. As the objective of this work was to explore the relationship between corporate governance variables and afirm's performance, a longer time period allowed the identification of changes in corporate governance policies and characteristics that impacted the company's performance. Conducting an analysis over a shorter period of time has drawbacks, as trends cannot always be seen, and looking at more historic data may not be relevant to the inner workings of the companies today. Therefore, a sample period of five years was selected where data was collected annually from 2013 to 2017.

Consequently, due to lack of information of companies, a panel data set was developed for this paper which comprises 12 listed Islamic banks covering a period of 2013 to 2017. Therefore, the number of observations for this study establishes a panel data set of 60 firmyear observations.

The following formula explains the calculation of the number of observations:

$$
\mathrm{N} \times \mathrm{T}=12 \times 5=60 \text { Observations }
$$

Where $\mathrm{N}$ represents the number of Islamic banks and $\mathrm{T}$ represents the number of years which is 5 .

\section{Definition of Operational Variables}

The variables used in this study are separated into the independent, dependent, and control variables and will be explained and interpreted. To measure the independent variables which are the internal corporate governance mechanisms, a number of methods will be used. The independent variables which are to be tested include; the size of the board (BSIZE), the ownership structure or CEO duality (DUAL), the board independence (NEDS) and the Shariah Supervisory Board size (SSBS). In order to measure the dependent variables which are the performance measures, two methods have been selected; return on asset (ROA) and return on equity (ROE). In addition, the study will incorporate control variables to manage a firm's characteristics that could influence or impact the performance of the company. The control variables chosen are the age of the firm (AGE) and the size of the firm measured in terms of size of assets (LSIZE).

\section{Data Analysis Technique}

\section{Regression (GLS)}

A Generalised Least Squared (GLS) Regression Model is the primary technique used to examine the influence of variables on 
Table 1. Summary of Variables

\begin{tabular}{|c|c|c|c|}
\hline Variable Name & $\begin{array}{l}\text { Variable } \\
\text { Category }\end{array}$ & Symbol & Definition \\
\hline Return on Asset & Dependent & ROA & Net Income/ Total Assets \\
\hline Return on Equity & Dependent & ROE & Net Income/Shareholder's Equity \\
\hline Board Size & Independent & BSIZE & $\begin{array}{l}\text { The total number of directors on the } \\
\text { board }\end{array}$ \\
\hline CEO Duality & Independent & DUAL & $\begin{array}{l}\text { Dummy variable is equivalent to ' } 1 \text { ' if } \\
\text { there is a dual role and ' } 0 \text { ' if separate role }\end{array}$ \\
\hline Board Independence & Independent & NEDS & $\begin{array}{l}\text { The percentage of non-executive directors } \\
\text { on the board }\end{array}$ \\
\hline $\begin{array}{l}\text { Sharia Supervisory } \\
\text { Board Size }\end{array}$ & Independent & SSBS & $\begin{array}{l}\text { The total number of members of the Sha- } \\
\text { ria Advisory Board }\end{array}$ \\
\hline Firm Age & Control & AGE & $\begin{array}{l}\text { The number of years of firm's existence } \\
\text { since year of incorporation }\end{array}$ \\
\hline Firm Size & Control & LSIZE & $\begin{array}{l}\text { The natural logarithm of the size of total } \\
\text { assets }\end{array}$ \\
\hline
\end{tabular}

the relationship between corporate governance characteristics and a firm's performance. GLS is used when there is a certain degree of correlation between variables or the variances of observations are unequal (heteroscedasticity).

This means that the GLS regression is more suitable for this data, as it accounts for variables which are not in this model. GLS is used over Ordinary Least Squared (OLS) when errors in each time period are uncorrelated with variables in the current time period and by using OLS it might lead to misleading results.

The GLS estimator is therefore used for the Random Effect Model which allows for tests related to cross sectional units (Gaur \& Delios, 2006).

A simple GLS regression with a single independent variable is shown below, which shows the linear relationship between the dependent variable $(Y)$ and the independent variable $(\mathrm{X})$.

$$
Y=\alpha+\beta X
$$

The study incorporates a variety of independent variables and therefore the model can be extended to incorporate the rest of the variables being tested.

$Y_{i}=\alpha+\beta_{1 X}+\beta_{2} X+\beta_{3 X}+\beta_{4 X}+\beta_{5 X}+$ $\beta_{6 X}+\varepsilon_{i}$

Where $\mathrm{Y}$ is the dependent variable; $\mathrm{X}$ is the independent variable known as the repressor; $\alpha$ is the intercept which indicates the value of the independent variable when the dependent variable is equal to $0 . \beta$ are the $\mathrm{n}$ coefficients for the $X$, which show the change in $Y$ that is associated with a unit change in $X$, when controlling for other independent variables in the model; and $\varepsilon$ is the error term.

2. Panel Data Approach

To further facilitate the reliability of the analysis of the relationship between corporate governance mechanism and firm performance, this paper will employ a panel data methodology. As explained by Gujarati (2003), in panel data, the crosssectional units (the firm) is surveyed over time. Therefore, panel data has space and time dimensions. Furthermore, an advantage of panel data, is that it accounts 
for observable and unobservable facts, such as heterogeneity, which has not been included in some previous work (Dezso \& Ross, 2012). Thus, the regression model will be adapted to include the effect of panel data:

$$
\mathrm{Y}_{\mathrm{it}}=\alpha+\beta X_{\mathrm{it}}+\mu_{\mathrm{it}}
$$

3. Regression Model

In order to test the hypotheses outlined, they will be tested against the following models:

Performance $=\alpha+\sum \beta_{1}$ Board size $+\beta_{2}$ CEO duality $+\beta_{3}$ Board Independence $+\beta_{4}$ Shariah Supervisory Board Size $+\beta_{5}$ Size of Asset $+\beta_{6}$ Age $+\mu+\varepsilon$

$$
\begin{aligned}
& \mathrm{ROA}=\alpha+\sum \beta_{1} \cdot \text { BSIZE }_{i t}+\beta_{2} \text {. DUAL } \mathrm{DU}_{\mathrm{it}}+ \\
& \beta_{3 . N E D S}+\beta_{\text {it }}+\beta_{4 . S B S}{ }_{i t}+ \\
& \beta_{5} . \text { LSIZE }_{\mathrm{it}}+\beta_{6} \cdot \mathrm{AGE}_{\mathrm{it}}+\mu_{\mathrm{it}}+\varepsilon_{\mathrm{it}} \\
& \text { ROE }=\alpha+\sum \beta_{1} \text { BSIZE }_{i t}+\beta_{2} \text {. DUAL } i t+ \\
& \beta_{3} . \text { NEDS }_{i t}+\beta_{4} \text { SSBS }_{\text {it }}+ \\
& \beta_{5} . \text { LSIZE }_{i t}+\beta_{6} . \text { AGE }_{i t}+\mu_{\mathrm{it}}+\varepsilon_{\mathrm{it}}
\end{aligned}
$$

Where:

$\mathrm{i}=$ the firm number, ranging from 1-12

$\mathrm{t}=$ the time period, ranging from $2013-$

2017

$\alpha=$ fixed variable (y-intercept)

$\beta_{1}-\beta_{4}=$ independent variables used and $\beta_{1}$ is the coefficient of the independent variables

$\beta_{5}-\beta_{6}=$ coefficients of the control variables

$\mu=$ unobservable random effect

$\varepsilon=$ error term

ROA and ROE represent the performance measure used which is the dependent variable.

4. Panel Data Methodology (Random and Fixed Effect)

Due to many past studies lacking variables and containing endogeneity problems, whereby the explanatory variable is correlated to the error term, fixed effect and random effect analysis will be undertaken. This is important when analysing panel data to achieve robust results for variables which have been omitted or not considered.

The Hausman Test is used to differentiate between random effects and fixed effect estimates. The null hypothesis $\left(\mathrm{H}_{0}\right)$ suggests that the Random Effect Model should be used, whereas the alternative hypothesis $\left(\mathrm{H}_{1}\right)$ suggests that the fixed effect model is appropriate, and the Hausman Test can identify this. The Hausman Test also generates a chi-squared probability and if that value is greater than the significant value $(5 \%)$ then the null hypothesis is accepted. As such the rule is shown below:

If $\mathrm{P}>0.05$, then accept $\mathrm{H}_{0}$ (Use the Random Effect Model)

If $\mathrm{P}<0.05$ then accept $\mathrm{H}_{1}$ (Use the Fixed Effect Model)

\section{RESULT AND DISCUSSION}

\section{Descriptive Statistics}

The table below (Table 2), provides the descriptive statistics generated by the econometric software Stata, of the research sample, which contains the number of observations, the sum of the variables, mean, standard deviation, maximum and minimum values. The mean of the dependent variable ROA (\%) is significantly lower than those found in Khan \& Awan (2012) and Rambajan (2011) studies which are 8.2 and 11.7 respectively. This is more in line with Haniffa and Hudaib's (2006) work which found a mean ROA of 2.56. The ROE dependent variable is seen to have a larger mean of 18.92 which is in line with Hassan \& Rizwans (2017) study and hada mean of 18.10, however it was much larger than Nomran et al. (2018) who reported a mean of 9.09 . 
Table 2. Descriptive Statistics

\begin{tabular}{ccccccc}
\hline Variables & N & Sum & Mean & SD & Max & Min \\
\hline ROE & 60 & 1,135 & 18.92 & 14.04 & 58.12 & -12.50 \\
ROA & 60 & 118.9 & 1.982 & 1.053 & 4.880 & -0.440 \\
LSIZE & 60 & 1,000 & 16.67 & 1.182 & 18.33 & 14.66 \\
AGE & 60 & 1,790 & 29.83 & 15.06 & 63 & 6 \\
BSIZE & 59 & 579 & 9.814 & 1.786 & 14 & 7 \\
DUAL & 59 & 6 & 0.102 & 0.305 & 1 & 0 \\
NEDS & 52 & 3,976 & 76.47 & 13.87 & 100 & 44.40 \\
SSBS & 60 & 268 & 4.467 & 1.214 & 8 & 3 \\
\hline
\end{tabular}

For the independent variable of board size, the mean is 9.8, suggesting that Islamic banks mainly have slightly larger numbers of members on the board, compared to Hannifa and Hudaib (2006) whose mean was 7.94 or 8.08 for Aljifri and Moustafa (2007) and 7.96 as found by Mashayekhi \& Bazaz (2008).

This further demonstrates that Islamic banks tend to have a higher number of members on the boardcompared to other firms within Asian countries; this could be to broaden the pool of expertise. As for the independent variable of non-executive directors (\%), the mean was observed to be 76.47 which was again, a much larger proportion of NEDs compared to Hannifa and Hudaib (2006) who reported 58.53, Hermalin, S. and M. Weisbach (1991) who found a mean of 55.90 and Mehran (1995) who saw a mean of 55.00. It can therefore be established that Islamic banks also have a substantially higher percentage of NEDs on their board, which supports the idea of agency theory by reducing the conflict of interest that insider directors may have.

For the independent variable of CEO duality, this study found that the mean was 0.102 which was due to only two firms in the sample which had adual role. This was much lower than Belkhir (2009) who reported a mean of 0.55 but much higher than Daly \& Frikha (2015) who saw a mean of 0 , indicating that in their sample of Islamic banks, none of the banks had a dual role. Furthermore, for the independent variable of Shariah Board Size, the mean was 4.47 which was double, in comparison to what Hassan \& Rizwan (2017) found, with a mean number of 2.09; however, it was inline with Nomran et al. (2018) which reported a mean number of members of 4.82 .

The control variable of age this paper's sample obtained, wasa range of ages from 6-63 years with a mean of 29.83 . The sample of Islamic banks seen in Belkhir (2009) had a range of 2-53 with a mean age of 18.51 . Similarly, Daly \& Frikha (2015) reported a range of ages to be 1-33 and a mean of 15 years. This could therefore be a factor to explain some differences witnessed within this study compared to other papers, as the mean was higher; this could indicate a better performance due to longevity within the industry. Furthermore, the Log Islamic Bank Size had a mean of 16.67 which was just lower than Rashid \& Jabeen's (2016) study on which a mean size of 18.54 was noted, whereas Akhtar et al. (2011) had a mean of 6.67 as they used smaller banks for their sample which explains the variations.

\section{Pearson Correlation Matrix}

The table below demonstrates the Pearson Correlation Matrix between all the variables included within this study. 
Table 3. Pearson Correlation Matrix Results

\begin{tabular}{ccccccccc}
\hline & ROE & ROA & LSIZE & AGE & BSIZE & DUAL & NEDS & SSBS \\
\hline ROE & 1 & & & & & & & \\
ROA & $0.691^{* * *}$ & 1 & & & & & & \\
LSIZE & 0.127 & $0.381^{* *}$ & 1 & & & & & \\
AGE & -0.0545 & $0.328^{*}$ & $0.374^{* *}$ & 1 & & & \\
BSIZE & 0.00235 & 0.161 & -0.116 & $-0.293^{*}$ & 1 & & \\
DUAL & $0.453^{* * *}$ & 0.123 & 0.242 & -0.252 & $-0.383^{* *}$ & 1 & & \\
NEDS & 0.177 & 0.179 & $0.439^{* *}$ & -0.213 & -0.0621 & $0.310^{*}$ & 1 & \\
SSBS & 0.174 & $0.409^{* *}$ & 0.204 & $0.390^{* *}$ & 0.112 & 0.168 & -0.265 & 1 \\
& & & & & & & & \\
\hline
\end{tabular}

The dependent variable ROE does not show much correlation to most variables however, it is highly correlated to ROA and CEO duality. It must be noted that since ROE and ROA will be used in different models, the models and the correlation between them will not influence the outcomes of this study. The lowest correlation is seen between ROE and age which means that age is a good variable to use as a control. ROA is also seen to be correlated to log size, Shariah Advisory Board size and age at the 5\%,5\% and $10 \%$ levels respectively. Log size also shows a significant correlation to between variables of age, as well as NEDs at the 5\% level and Board size and CEO duality also show a negative correlation at the 5\% level. Age and BSIZE also see correlations that are negative which Rashid et al. (2010) also report and there is a similar significance between CEO duality and NEDs at the $10 \%$ level.

Furthermore, since all the correlation coefficients are less than 0.95, there is no concern of collinearity between the variables and, as such all the independent variables can be used within the regression model (Gujarati \& Porter, 2009).

\section{The Hausman Test}

The Hausman test was conducted to check if the Fixed Effect or Random Effect Model was best used for the data. The Hausman Test results for the ROE model was 0.85 and so the ROA model is 0.3374 . Therefore, since the $\mathrm{P}$ value of the Hausman Tests are less than 5\%, it means that the Random Effect
Model is the most suitable to estimate the models. It can thereforebe said, that the effects of board size and CEO duality on firm performance provide robust results, however, none of the other independent or control variables have an impact on firm performance.

\section{Regression GLS Results}

The results of the GLS regression are shown in the table below for each dependent variable. The first column shows the relationship between the independent variables and firm performance as measured by ROE and the second column shows the relationship between the independent variable and ROA.

From the first regression it can be seen that the P value of the F statistic is less than 0.05 at the significance level, therefore, it can be said that all the independent variables simultaneously explain the dependent variable, which is ROA in this case. The R-squared value has been generated at 0.4333 which means that there is a $43.33 \%$ variation of ROA that can be explained by variation of all the independent variables in the model. This means that the remaining $56.67 \%$ is unexplained and therefore it must be due to unmeasured potential confounding variables that are outside of the model.

As shown in the Random Effect Model, we can see that there is enough evidence at significance level of $5 \%$ for BSIZE to have a positive impact on ROA. This means that an increase of one board member is expected to increase ROA by an average of 0.155 . 
Table 4. GLS Estimate Results

\begin{tabular}{lcc}
\hline & Return on Equity (ROE) & Return on Asset (ROA) \\
\hline \multirow{2}{*}{ Constant } & 38.50 & -0.14 \\
& 0.83 & -0.631 \\
BSIZE & 0.96 & 0.15 \\
& 1.38 & 2.25 \\
DUAL & 21.41 & 0.97 \\
& 1.73 & 0.05 \\
NEDS & 0.21 & 0.13 \\
& 1.51 & 0.25 \\
SSBS & 0.105 & 0.10 \\
& 0.05 & 0.76 \\
LSIZE & -4.04 & -0.14 \\
& -1.15 & -0.48 \\
AGE & 0.22 & 0.03 \\
R- Squared & 0.73 & 1.34 \\
Number of Firms & 0.3673 & 0.4333 \\
Observations & 12 & 12 \\
\hline
\end{tabular}

Furthermore, any Islamic bank with CEO duality, is expected to have a higher ROA, by 0.974 on average, than those that have a separate role at a significance level of $10 \%$. As for the other independent variables and control variables, there is not enough evidence to suggest that the size of assets, age, NEDs and Shariah Advisory Board size impact the ROA at any significant level.

From the second random effect GLS regression, it is shown that the $\mathrm{P}$ value of the $\mathrm{F}$ statistic is also less than 0.05 significance level and therefore,it can also be concluded that all the independent variables simultaneously explain the dependent variable. The R-squared in this case is 0.3673 which means that $36.73 \%$ variation of $\mathrm{ROE}$ can be explained by a variation of all the independent variables in the model.

This signifies that a further $63.27 \%$ is due to other factors or variables that are not included in the model. From the Random Effect Model related to ROE, it shows that there is enough evidence to suggest a relationship between CEO duality and ROE at a significance level of $10 \%$. This means that any Islamic banks with CEO duality, are expected to have a higher ROE by 21.415 on average, compared to those with a separate role. The other independent variables and control variables do not see any significant relationship on a firm's performance.

\section{CONCLUSION}

The aim of this study was to investigate the relationship between corporate governance and Islamic bank performance. From the findings of the research obtained, it can be concluded that corporate governance is a fundamental factor which influences the functioning of Islamic banks by aligning the interests of shareholders and managers. Due to the different rules and regulations that Islamic banks are subject to, it is important to consider their various corporate governance policies. Some past studies have concluded that there are many different corporate governance variables which determine performance, whilst 
others have found little significance and argue that a different set of variables influences a firm's performance.

The methodological approach followed shows correlations and regressions to assess the significance of the four independent variables on the two dependent variables. The study produced a variety of mixed results which is similar to previous work done within this field, however, some interesting observations were nevertheless obtained. The research findings demonstrated that board of director characteristics, such as board size and particularly leadership structure (CEO duality), have indeed impacted the performance of Islamic banks between the periods of 2013 and 2017. Board size was seen to have the largest significance on performance measured by ROA, however, CEO/Chairman separation saw a significant relationship between ROA and ROE. However, from the random effect models it can be deduced that there are many more potential confounding factors which will also affect the performance of the Islamic banks.

It can also be said that Islamic banks are not exempt from the effects of bad corporate governance; as stated in the beginning of the study, many Islamic banks have collapsed due to poor mechanisms. Moreover, different companies have different laws and approaches regarding corporate governance policies which could influence their perception of what measures are best for ensuring prolonged improved performance.

Some limitations encountered through the course of this study relate to the availability of data and time constraints. The data collected, initially aimed to look at the top 20 banks within the Islamic banking industry worldwide, based on size of assets. However, due to different disclosure requirements and limited availability of data on databases, such as Orisis, the sample was reduced to 12 banks some of which were not the largest Islamic banks. Furthermore, as time was limited, this reduced the number of variables included and availability of data from more than five years ago, also raised issues.

Upon completion of this study, further research could explore measuring performance using different variables, as well as expanding the sample and number of years looked at. This study could be expanded by increasing the sample size from 12 to 20 , to expand the number of years looked atand to use larger, more established Islamic banks. As well as the variables included in this study, one could explore measuring performance using other corporate governance variables, such as Sharia Board Independence and Audit Committee independence. Moreover, further studies could consider the comparison between conventional and Islamic banking corporate governance variables to investigate which method has a larger effect on banking performance.

\section{REFERENCES}

Ahmed, H., and Chapra, M. (2002). Corporate Governance in Islamic Financial Institution (Occasional Paper). The Islamic Research and Teaching Institute (IRTI).

Akhtar, M., Ali, K., and Sadaqat, S. (2011). Factors Influencing the Profitability of Islamic Banks of Pakistan. International Research Journal of Finance and Economics, 66, 125-132

Aljifri, K., and Moustafa, M. (2007). he Impact of Corporate Governance Mechanisms on the Performance of UAE Firms: An Empirical Analysis. Journal of Economic and Administrative Sciences, 23(2), 71-93.

Belkhir, M. (2009). Board structure, ownership structure and firm performance: evidence from banking. Applied Financial Economics, 19(19), 1581-1593.

Daly, S., and Frikha, M. (2015). Corporate governance: what about Islamic banks? Int. J. Financial Services Management, $8(1), 18-41$. 
Dezso, C. a. (2012). Does female representation in top management improve firm performance? A panel data investigation. Strategic Management Journal, 33(1), 1072 - 1089.

Gaur, S., and Delios, A. (2006). Business Group Affiliation and Firm Performance During Institutional Transition. Paper presented at the Academy of Management Proceedings.

Global Islamic Finance Report (GIFR). (2017). GIFR. London: Edbiz Consulting.

Gujarati, D. (2003). Basic Economics. McGraw Hill.

Gujarati, D., and Porter. (2009). Basic Econometrics. McGraw-Hill Education.

Haniffa, R., and Hudaib, M. (2006). Governance Structure and Performance of Malaysian Listed Companies,. Journal of Business Finance and Accounting, 33(6/7), 1034-1062.

Hassan, M., Rizwan, M., and Sohail, H. (2017). Corporate Governance, Shariah Advisory Boards and Islamic Banks' Performance. Pakistan Journal of Islamic Research, 18(1), 173-184.

Hermalin, B. and Weisbach, M.S. (1991). The Effects of Board Composition and Direct Incentives on Firm Performance. FM: The Journal of the Financial Management Association, 20(4), 101-112.

Khan, A., and Awan, S. (2012). Effect Of Board Composition On Firm's Performance: A Case Of Pakistani Listed Companies. Interdisciplinary Journal Of Contemporary Research In Business, 3(10), 853-863.

Mashayekhi, B., and Bazaz, M. (2008). Corporate Governance and Firm Performance in Iran. Journal of Contemporary Accounting \& Economics, 4(2), 156-172.

Mehran, H. (1995). Executive compensation structure, ownership, and firm performance. Journal of Financial Economics, 38(2), 163-184.

Nomran, N., Haron, R., and Hassan, R. (2018). "Shari'ah supervisory board characteristics effects on Islamic banks' performance: Evidence from Malaysia. International Journal of Bank Marketing, 36(2), 290-304.

Otman, K. (2014). Corporate Governance and Firm Performance in Listed Companies in the United Arab Emirates. United Arab Emirates.

Price, R., Román, F., and Rountree, B. (2011). The impact of governance reform on performance and transparency. Journal of Financial Economics, 99(1), 79-96.

Rambajan, A. (2011). The relationship between corporate governance and company performance . Pretoria: University of Pretoria.

Rashid, A. D. (2010). Board composition and firm performance: evidence from Bangladesh. Australasian Accounting Business and Finance Journal, 4(1), 76-95.

Rashid, A., and Jabeen, S. (2016). Analyzing performance determinants: Conventional versus Islamic Banks in Pakistan. Borsa Istanbul Review, 16(2), 92-107.

Samra, E. (2016). Corporate Governance in Islamic Financial Institutions. Chicago: University of Chicago Law School.

Vaughn, M., and Ryan, L.V. (2006). Corporate Governance in South Africa: a bellwether for the continent? Corporate Governance: An International Review, 14(5), 504-512. 